\title{
Application of Statistical Methods in Evaluating Groundwater in Parts of Mamfe Embayment, Southeastern Nigeria
}

\author{
Anthony Ugbaja ${ }^{1}$, Aniekan Edet $^{1} \&$ Offiong Offiong ${ }^{2}$ \\ ${ }^{1}$ Department of Geology, University of Calabar, Calabar, Nigeria \\ ${ }^{2}$ Department of Chemistry, University of Calabar, Calabar, Nigeria \\ Correspondence: Anthony Ugbaja, Department of Geology, University of Calabar, Calabar, Nigeria. E-mail: \\ anthonyugbaja@yahoo.com
}

Received: May 2, 2012 Accepted: May 25, 2012 Online Published: June 15, 2012

doi:10.5539/jgg.v4n3p1

URL: http://dx.doi.org/10.5539/jgg.v4n3p1

\begin{abstract}
Eighty eight (88) water samples were collected from twenty two (22) locations across four periods to highlight the micro-climatic conditions between January to September 2005 in three Formations intrusive, Asu River group and Eze-Aku. In this study, the relationship between various elements has been studied using correlation analysis, cluster analysis and factor analysis. The data also show that the aquifer in the study area are vulnerable to faecal coliform due to water from runoff that infiltrate into the aquifer from the vodose zone during precipitation in the area. This is evidence that the vulnerability of the study area is control by infiltration and runoff.
\end{abstract}

Keyword: groundwater, correlation analysis, cluster analysis, factor analysis, Mamfe Embayment, Cross River State, Nigeria

\section{Introduction}

The vulnerability potential of an aquifer to groundwater contamination is to a large extent a function of the susceptibility of its recharge area to infiltration. Areas that are replenished at a fast rate are generally more vulnerable to contaminant than those replenished at a slower rate. Aquifers that do not have a cover of dense material are susceptible to contamination. Bedrock areas with large fractures are also susceptible by providing pathways for the contaminants. Confined, deep aquifers tend to be better protected with a dense layer of clay material (Kim \& Hamm, 1999).

Ground water pollution is caused by a variety of substances originating from many different activities. Most of the contaminants that commonly cause concern originate above ground, often as the result of human activities. After release at the land surface, the contaminant may infiltrate downward through the soil overlying the water table which provides the primary protection against groundwater pollution in unconfined aquifers, because sediment and other insoluble forms of contamination become trapped within the soil pores. Some chemical are absorbed or react chemically with various soil constituents, thereby preventing or slowing the migration of these pollutants into the groundwater. In addition plants and soil microorganism use some potential pollutants such as nitrogen, as nutrients for growth, thereby depleting the amount that reaches the groundwater (Hearne et al., 1992).

\subsection{Study Area}

The study area lies between latitudes $5^{\circ} 15^{\prime}$ and $6^{\circ} 15^{\prime} \mathrm{N}$ and longitudes $7^{\circ} 45^{\prime}$ and $8^{\circ} 45^{\prime} \mathrm{E}$ (Figure 1). It is located within the sub-equatorial climatic region of Nigeria with a total annual rainfall of more than 300 to $400 \mathrm{~cm}$. The temperature ranged from $25^{\circ} \mathrm{C}$ to $28^{\circ} \mathrm{C}$. The area experiences two seasons, these are the wet season which lasts from April to September with a peak in June and July while the dry seasons lasts from October to March (Iloeje, 1991). The elevation of the study area ranged from 14 to $170 \mathrm{~m}$ above sea level. The relief is characterized by undulations running at undefined direction and variably demarcating the very lowland areas from moderate relief landmarks. The occurrence of the low plains is occasionally broken by inselbergs of granite and basalts in the southern portion of the study area. In the sediment filled portions, the low plains are occasionally broken by flat topped hills of sandstone ridges and igneous intrusive with highly ferroginized sandstones with gravels resulting from uplifts. The area is drained by the Cross River with major tributaries like, Udip, Ukong, Lakpoi, Okwo, and Okpon rivers (Figure 1). These rivers form a network of dendritic drainage system. The minor rivers and or 
streams that feed these major ones are, however, perennial and trace their origin from the Enugu escarpment and the Cameroon highlands.

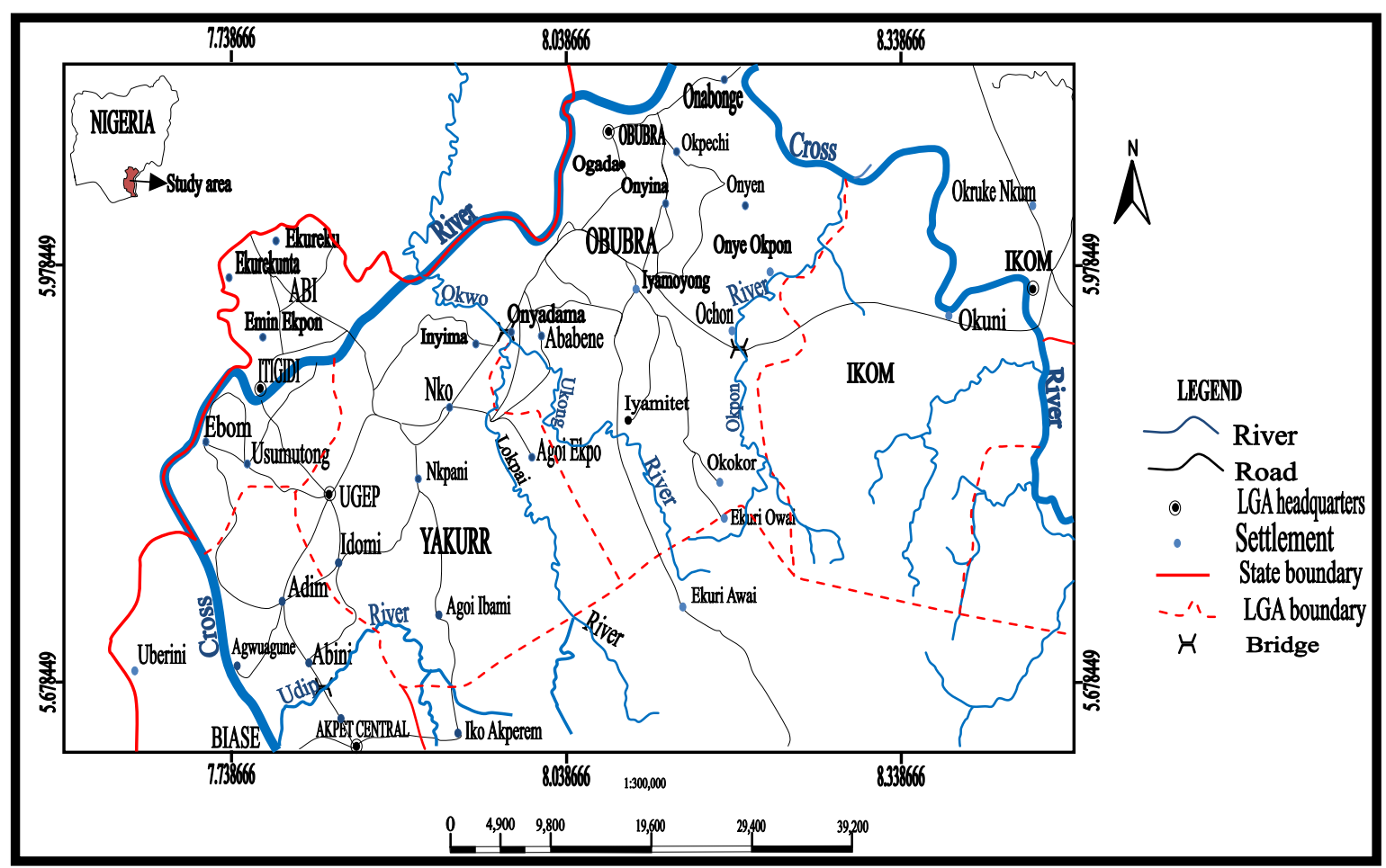

Figure 1 . The drainage pertains of the study area/settlement

\subsection{Geology and Hydrogeology}

The study area is underlain by two major lithologic units: Crystalline basement and Cretaceous sediments. The crystalline basement rocks occupy the extreme south of the study area. Also, there are intermediate rocks scattered in patches around Obubra, Iyamayong, Iyamitet, Ikom, Nkpani and Usumutong (Figure 2). The Cretaceous sediments cover about $90 \%$ of the study area. Asu River Group is the basal and oldest recorded sediment in the study area. It is dominated by bluish gray/black to olivine brown shale and sandy shale, fine - grained micaceous calcareous sandstone and siltstone with limestone lenses. The shale is often carbonaceous and pyritic which indicates that the sediments were deposited under a poorly oxygenated shallow water environment of restricted circulation, an indication of low energy environment (Petters et al., 1987).

In basement provinces groundwater occurrence depend exclusively on discontinuities like fractures, joints, fissures, and weathered litho - zones. The fissures of crystalline rocks are limited to shallow depths, and water movement is lateral in the direction of the gradient downwards to the drainage area. Fracturing and fissuring is a common phenomenon in basalts because of the tectonic chilling effects on them, which develops fractures. About $60 \%$ of ground water is habited in weathered - fresh bedrock transition with aquifer yields of $0.2-3.5 \mathrm{l} / \mathrm{sec}$. (CRBDA, 1982). According to Petters (1989) recharge to the weathered zones and joints system is greatly retarded in significantly lateritic cover areas. This is attributed to the high content of the impermeable clay in the laterite. CRBDA (1982) put the yield for this province (weathered zones) at $84.4-345.6 \mathrm{~m}^{3} /$ day. Static water level (SWL) is between $4.6-19.8 \mathrm{~m}$ in Obubra and $12.2-21.4 \mathrm{~m}$ for part of Ikom in the study area. Boreholes depths range between $25-47 \mathrm{~m}$ in the study area. Shale - sandstone or shale/siltstone province is the largest hydro geological province in the study area, occupying about $70 \%$ of the study area. This area cuts across locations like Obubra, Apiapum, Nko, Ekori, Ugep, Ochom, and Agara Ekureku (Figure 2). It constitutes the geologic Asu River Group and Eze - Aku formation. These sediments are slightly folded, tilted and at times broken by faults. Fractures, fissures and joints commonly occur in sandstones and sandstone affiliated sediments, but are commonly restricted to shallow depths of $20-50 \mathrm{~m}$. Permeability of the study area is influenced by the nature and texture of the sediment type, constituting the study area. For example permeability is moderate in porous, fissured and fractured 
sandstone/Shale but very low in impervious shale and siltstones. Shale/siltstones province record very low aquifer yield of $0.05-0.5 \mathrm{l} / \mathrm{sec}$, while some sub area like siltstone/limestone record up to $2.02 \mathrm{l} / \mathrm{sec}$ (CRBDA, 1982).

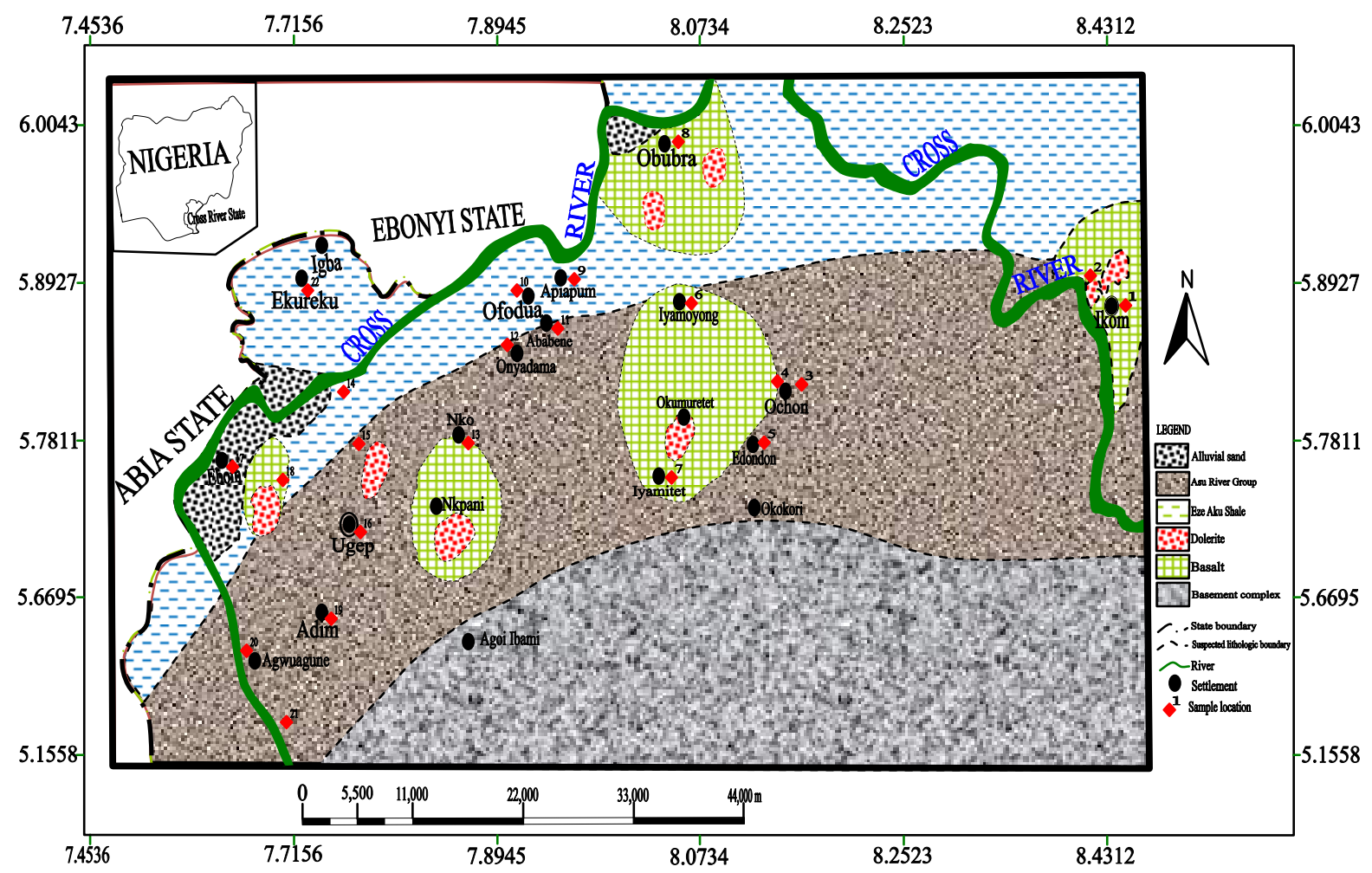

Figure 2. Geologic /sample location map of the study area

\section{Methods}

Water samples were collected from various locations within the study area (Figure 2). Using pre-washed two liter polythene plastic bottles for chemical and biological analysis while $250 \mathrm{ml}$ polythene plastics were used to collect samples for heavy metals. The samples for heavy metals analysis were acidified to $\mathrm{pH}$ of 2 using nitric acid. The Physical parameters; Color, dissolved oxygen, $\mathrm{pH}$, conductivity and temperature were determined in the field using standard field equipment. The groundwater samples were analyzed in the laboratory using standard methods (Table 1).

Table 1. Field/laboratory features and equipment used for the analysis

\begin{tabular}{ccc}
\hline Parameters & Standard Methods / Equipment & Locations \\
\hline Temperature/conductivity & WTW LF 91 meter & Field \\
pH & WTW ph 90 meter & $"$ \\
Dissolved Oxygen DO) & WTW oximeter 96 & $"$ \\
Color & Lau bond comparator & University of Calabar \\
Alkalinity & Titrimetric method & $"$ \\
Total hardness & $"$ & $"$ \\
Calcium & $"$ & $"$ \\
Magnesium & $"$ & $"$ \\
Chlorine & $"$ & $"$ \\
Potassium & $"$ &
\end{tabular}




\section{Sodium}

THB

Faecal Coli form

Total Coli form

Ammonium salt

Nitrate

Nitrite

Phosphate

Sulphate

Iron

Zinc

Manganese
"1

Counting of Aerobic mesophilic Bacteria

"

DR/4000u Spectrophotometer

"

$"$

"

$"$

"

\section{$"$}

Dept. of Biology, University of Calabar

"

Oceanography University of Calabar

"I

"

"

"

"

"

\section{Results}

The Static water level ranged from 0 to $14 \mathrm{~m}$ with the lowest mean value of $1.56 \mathrm{~m}$ in Eze-Aku Formation while the highest mean value of $6.47 \mathrm{~m}$ was recorded in the intrusive. Temperature ranged from $24^{\circ} \mathrm{C}$ to $32.2^{\circ} \mathrm{C}$ with the lowest mean value of $28.29^{\circ} \mathrm{C}$ in intrusive and highest mean value of $28.76^{\circ} \mathrm{C}$ in Eze-Aku Formation. The high temperature may be attributed to the physiographic condition of the area. Conductivity ranged from 27.4 to $1141 \mu \mathrm{s} / \mathrm{cm}$ with the lowest mean value of $185.34 \mu \mathrm{s} / \mathrm{cm}$ in intrusive and the highest mean value of $417.46 \mu \mathrm{s} / \mathrm{cm}$ in Eze-Aku Formation. pH varied from 4.1 to 9.1 with the lowest mean value of 6.86 in Asu-river group and the highest mean value of 7.25 in the intrusive. The low $\mathrm{pH}$ may be attributed to subsurface runoff and organic waste while the high $\mathrm{pH}$ may be due to a decrease in the dissolved solute. Color varied from 0 (Pt-Co) to 127 (Pt-Co) with the lowest mean of 25.50 (Pt-Co) in intrusive and the highest mean value of 39.5 (Pt-Co) in Asu River Group. Udom et al. (1998) attributed the high value of color to iron contamination in water. DO (dissolved oxygen) ranged from 0 to $6.6 \mathrm{mg} / \mathrm{l}$ with the lowest mean value of $3.15 \mathrm{mg} / \mathrm{l}$ in Eze-Aku Formation and the highest mean value of $4.31 \mathrm{mg} / \mathrm{l}$ in intrusive. BOD values ranged from 0.7 to $24 \mathrm{mg} / 1$ with the lowest mean value of $0.34 \mathrm{mg} / 1$ in Asu-River group and a high of $0.48 \mathrm{mg} / 1$ in Eze-Aku Formation. Total hardness varied from $12 \mathrm{mg} / 1$ to $2456 \mathrm{mg} / 1$ with the lowest mean value of $280.83 \mathrm{mg} / \mathrm{l}$ in intrusive and the highest mean value of $530.29 \mathrm{mg} / \mathrm{l}$ in Eze-Aku Formation. Alkalinity and total hardness are usually nearly equal in concentration (when they are both reported in $\mathrm{mg} / \mathrm{l} \mathrm{CaCO}$, because they form from the same minerals (Spurlock, 2005). Alkalinity varied from 30mg/l to 1090mg/l with the lowest mean value of $164.13 \mathrm{mg} / 1$ in intrusive and the highest mean value of $343.86 \mathrm{mg} / \mathrm{l}$ in Eze-Aku Formation. Sodium $\left(\mathrm{Na}^{+}\right)$varied from a low of $9.2 \mathrm{mg} / 1$ to a high of $386.2 \mathrm{mg} / 1$ with the lowest mean value of $30.19 \mathrm{mg} / \mathrm{l}$ in intrusive and the highest mean value of $73.60 \mathrm{mg} / 1$ in Eze-Aku Formation. Higher concentrations of Sodium usually indicate contamination by septic systems, road salt, fertilizer, animal waste or other wastes. Potassium $\left(\mathrm{K}^{+}\right)$ ranged from $0.3 \mathrm{mg} / 1$ to $12.1 \mathrm{mg} / \mathrm{l}$ with the lowest mean value of $0.93 \mathrm{mg} / \mathrm{l}$ in intrusive and the highest mean value of $2.28 \mathrm{mg} / \mathrm{l}$ in Eze-Aku Formation. Calcium $\left(\mathrm{Ca}^{2+}\right)$ ranged from $2.4 \mathrm{mg} / 1$ to $347.9 \mathrm{mg} / 1$ with the lowest mean value of $43.14 \mathrm{mg} / \mathrm{l}$ in intrusive and the highest mean value of $93.25 \mathrm{mg} / 1$ in Eze-Aku Formation. Magnesium $\left(\mathrm{Mg}^{2+}\right)$ varied from $0 \mathrm{mg} / \mathrm{l}$ to $534 \mathrm{mg} / \mathrm{l}$ with the lowest mean value of $49.95 \mathrm{mg} / \mathrm{l}$ in intrusive and the highest mean value of $86.02 \mathrm{mg}$ in Eze-Aku Formation. Most concentrations are higher than the WHO values of 100mg/l for Calcium and $50 \mathrm{mg} / \mathrm{l}$ for Magnesium. As water moves through soil and rock, it dissolves very small amounts of minerals and holds them in solution. Calcium and magnesium dissolved in water are the two most common minerals that make water "hard". The degree of hardness becomes greater as the calcium and magnesium content increases and is related to the concentration of multivalent cations dissolved in the water. Ammonium $\left(\mathrm{NH}_{4}^{+}\right)$ranged from $0.01 \mathrm{mg} / \mathrm{l}$ to $10.7 \mathrm{mg} / 1$ with the lowest mean value of $0.40 \mathrm{mg} / 1$ in intrusive and the highest mean value of $1.39 \mathrm{mg} / 1$ in Eze-Aku Formation. Bicarbonate $\left(\mathrm{HCO}_{3}{ }^{-}\right)$ranged from $36 \mathrm{mg} / 1$ to $1308 \mathrm{mg} / \mathrm{l}$ with the lowest mean value of $196.95 \mathrm{mg} / \mathrm{l}$ in intrusive and the highest mean value of $412.63 \mathrm{mg} / \mathrm{l}$ in Eze-Aku Formation. Chloride $\left(\mathrm{Cl}^{-}\right)$varied from $14.2 \mathrm{mg} / 1$ to $603.5 \mathrm{mg} / 1$ with the lowest mean value of $46.60 \mathrm{mg} / \mathrm{l}$ in intrusive and the highest mean value of $113.86 \mathrm{mg} / \mathrm{l}$ in Eze-Aku Formation. The high concentration may be due to contamination by septic systems, road salt, fertilizer, animal waste, landfills, or other wastes. Chlorides are salts resulting from the combination of the gas chlorine with a metal. Some common chlorides include sodium chloride $(\mathrm{NaCl})$ and magnesium chloride $\left(\mathrm{MgCl}_{2}\right)$. Chlorine alone as $\mathrm{Cl}_{2}$ is highly toxic and it is often used as a disinfectant. In combination with a metal such as sodium it becomes essential for life. Small amounts of chlorides are required for normal cell functions in plant and 
animal life. Chlorides are not usually harmful to people; however, the sodium part of table salt has been linked to heart and kidney disease. Sodium chloride may impart a salty taste at $250 \mathrm{mg} / \mathrm{l}$; however, calcium or magnesium chlorides are not usually detected by taste until levels of $1000 \mathrm{mg} / \mathrm{l}$ are reached. The amount of chlorine that reacts with the other chemicals plus the amount required to achieve disinfection is the chlorine demand of the water. Chlorides may get into surface water from several sources including rocks containing chlorides, agricultural runoff, wastewater from industries, oil well wastes, effluent wastewater from wastewater treatment plants, and road salting. Chlorides can corrode metals and affect the taste of food products. Therefore, water that is used in industry or processed for any use has a recommended maximum chloride level. Chlorides can contaminate fresh water streams and lakes. Fish and aquatic communities cannot survive in high levels of chlorides (Farrar, 1997; Jacks, 1973). Nitrate $\left(\mathrm{NO}_{3}{ }^{-}\right)$ranged from $0.4 \mathrm{mg} / 1$ to $4.8 \mathrm{mg} / 1$ with the lowest mean value of $2.18 \mathrm{mg} / 1$ in intrusive and the highest mean value of $2.60 \mathrm{mg} / \mathrm{l}$ in Eze-Aku Formation. Sulphate $\left(\mathrm{SO}_{4}{ }^{2+}\right)$ ranged from $0 \mathrm{mg} / 1$ to $0.68 \mathrm{mg} / \mathrm{l}$ with the lowest mean value of $0.01 \mathrm{mg} / 1$ in intrusive and the highest mean value of $0.15 \mathrm{mg} / 1$ in Eze-Aku Formation. Nitrate $\left(\mathrm{NO}_{3}{ }^{-}\right)$is a common inorganic form of nitrogen, chemically; it is an anion with a single negative charge, consisting of one atom of nitrogen and three atoms of oxygen. Because it is an anion, it is soluble in water. Plants normally use nitrate as their source of the nitrogen needed by all living things, and so nitrate is considered a nutrient for plants. Excessive concentrations of nitrate in lakes and streams greater than about 5 milligrams per liter (measured as nitrogen), depending on the water body, can cause excessive growth of algae and other plants, leading to accelerated eutrophication or "aging" of lakes, and occasional loss of dissolved oxygen. If nitrate-nitrogen exceeds 10 milligrams per liter in drinking water, it can cause a condition called methemoglobinemia or "blue baby syndrome" in infants (Fan et al., 1987). Some studies have indicated a possible connection between elevated nitrate concentrations and cancer (US Geological Survey, 2004). Nitride $\left(\mathrm{NO}_{2}^{-}\right)$varied from 0 to $1.5 \mathrm{mg} / 1$ with the lowest mean value of $0.02 \mathrm{mg} / \mathrm{l}$ in intrusive and the highest mean value of $0.24 \mathrm{mg} / 1$ in Eze-Aku Formation. Phosphate $\left(\mathrm{PO}_{4}{ }^{3-}\right)$ varied from $0.03 \mathrm{mg} / \mathrm{l}$ to $2.41 \mathrm{mg} / \mathrm{l}$ with the lowest mean value of $0.19 \mathrm{mg} / \mathrm{l}$ in Asu-River group and the highest mean value of $0.46 \mathrm{mg} / 1$ in Eze-Aku Formation. Sulphate $\left(\mathrm{SO}_{4}{ }^{2-}\right)$ and Phosphate $\left(\mathrm{PO}_{4}{ }^{3-}\right)$ are within WHO standard values, Phosphates are not toxic to man or animals unless they are present in very high levels. Digestive problems could occur from extremely high levels of phosphate (D'Angelo, 2001). Total Iron (mg/l) ranged from $0 \mathrm{mg} / 1$ to $2.4 \mathrm{mg} / 1$ with the lowest mean value of $0.05 \mathrm{mg} / 1$ in Asu-River group and the highest mean level of $0.19 \mathrm{mg} / \mathrm{l}$ in Eze-Aku Formation. Zinc $(\mathrm{Zn})$ varies from $0 \mathrm{mg} / \mathrm{l}$ to $0.14 \mathrm{mg} / 1$ with the lowest mean value of $0 \mathrm{mg} / \mathrm{l}$ in Asu-River group and the highest mean value of $0.02 \mathrm{mg} / \mathrm{l}$ in intrusive. Total Manganese $(\mathrm{mg} / \mathrm{l}) \mathrm{ranged}$ from $0 \mathrm{mg} / 1$ to $24 \mathrm{mg} / 1$ with the lowest mean concentration of $1.05 \mathrm{mg} / \mathrm{l}$ in intrusive and the highest mean concentration of $6.01 \mathrm{mg} / \mathrm{l}$ in Eze-Aku Formation. Total Iron (Fe), Total Manganese (mg/l) values were higher than the WHO values, while Zinc ( $\mathrm{Zn})$ was below WHO value. Dissolved ferrous iron gives water a disagreeable taste. When the iron combines with tea, coffee and other beverages, it produces an inky, black appearance and a harsh, unacceptable taste. Manganese is too reactive a metal to be found in elemental form in nature but its ore, the black dioxide pyrolusite, is widely distributed. The high concentration of metals in groundwater may be attributed to biodegradation of organic wastes which may lead to the release of these metals which are in turn leached into the water by the process of desorption. Most other element follow the same pattern exception of $\mathrm{PO}_{4}{ }^{3-}, \mathrm{Fe}$ and $\mathrm{Zn}$ which had their low concentration in Asu-River group and high concentration in Eze-Aku Formation. Total heterotrophic bacteria (THB) ranged from 0 to $25.47 \mathrm{cfu} / \mathrm{ml}$ with the lowest mean value of $1.78 \mathrm{cfu} / \mathrm{ml}$ in intrusive and the highest mean value of $2.87 \mathrm{cfu} / \mathrm{ml}$ in Eze-Aku Formation. The presence of fecal coliform in drinking water is evidence that human or animal waste has been or is present. This may be cause for concern because many diseases can be spread through fecal transmission. Escherichia coli, is a specific type of fecal coliform, the coliform group that lives in the intestines of humans and other warm-blooded animals and in their waste. Human illnesses such as typhoid, dysentery, cholera, hepatitis, and giardiasis have been linked to drinking water contaminated by human waste (Brunett et al., 1997). Faecal coliform varied from 0 to $16 \mathrm{cfu} / \mathrm{ml}$ with the lowest mean value of $0.92 \mathrm{cfu} / \mathrm{ml}$ in intrusive and the highest mean value of $2.56 \mathrm{cfu} / \mathrm{ml}$ in Eze-Aku Formation. Total Coliform bacteria are live organisms, and they can multiply rapidly or die off quickly, depending upon water temperature and other variables like Chlorine and Iodine which kills bacteria, including disease-causing organisms and the nuisance organism. Iron bacteria, this naturally occurring bacterium does not cause disease, but does form a reddish brown slime that coats the inside of pipes, fouls pumps and clogs waters (Dorsch, 1984). Coliform ranged from $2 \mathrm{cfu} / \mathrm{ml}$ to $134 \mathrm{cfu} / \mathrm{ml}$ with the lowest mean value of $3.58 \mathrm{cfu} / \mathrm{ml}$ in intrusive and the highest mean value of $16.22 \mathrm{cfu} / \mathrm{ml}$ in Eze-Aku Formation. 


\subsection{Statistical Analysis}

\subsubsection{Correlation Analysis}

Bivariate correlation analysis method is applied to describe the degree of relation between two hydrogeochemical parameters. The results of the correlation analysis are given in (Tables 2-5). A high correlation coefficient (near 1 or -1) means a good relationship between two variables and its value around zero means no relationship between them at a significant level of $p<0.05$. More precisely, it can be said that parameters showing $r>0.7$ are considered to be strongly correlated whereas $r$ between 0.5 and 0.7 shows moderate correlation (Manish et al., 2006). In this study, the relationship between various elements has been studied using Spearman rank coefficient which is based on the ranking of the data. The resultant matrix (Tables 2-5) reveals strong correlation of $\mathrm{Na}^{+}$with $\mathrm{Cl}^{-}, \mathrm{K}^{+}$with $\mathrm{Cl}^{-}$, and $\mathrm{Na}^{+}$with $\mathrm{K}^{+}$in all the periods (dry, dry-wet, wet, and wet-dry), some pairs of species show moderate to strong correlation $(\mathrm{r}>0.6)$, examples $\mathrm{NH}_{4}{ }^{+}-\mathrm{NO}_{2}{ }^{-}, \mathrm{NH}_{4}{ }^{+}-\mathrm{SO}_{4}{ }^{2-}$ (dry period). The major exchangeable ions $\mathrm{Na}-\mathrm{Cl}$ and $\mathrm{Na}-\mathrm{k}$ correlate positively and correlation coefficient is found to be same for all the period (Tables 2-5). It can therefore be said that the concurrent increase in the cations is the result mainly of precipitation reaction and concentration effects. The geochemical behavior of Magnesium, however, is substantially different from that of calcium. Magnesium ions are smaller than sodium or calcium ions and, therefore, have a stronger charge density and a greater attraction for water molecules. Magnesium is typically a constituent of dark-colored ferromagnesian minerals which include olivine, pyroxenes and dark colored micas. Sedimentary forms of magnesium include carbonates such as magnesite and mixtures of magnesium with calcium carbonate. The dissolution and weathering of some of these carbonate rock will introduce magnesium and $\mathrm{HCO}_{3}{ }^{-}$into the water.

Table 2. Correlation coefficient of element in Dry period

\begin{tabular}{lccccccccccc}
\hline $\mathrm{Ca}^{2+}$ & 1 & & & & & & & & & \\
$\mathrm{Cl}^{-}$ & 0.201 & 1 & & & & & & & & \\
$\mathrm{Na}^{+}$ & 0.204 & 0.999 & 1 & & & & & & & \\
$\mathrm{~K}^{+}$ & 0.202 & 0.999 & 0.999 & 1 & & & & & & \\
$\mathrm{Mg}^{2+}$ & 0.289 & 0.254 & 0.256 & 0.252 & 1 & & & & & \\
$\mathrm{NH}_{4}^{+}$ & 0.315 & 0.363 & 0.361 & 0.364 & 0.46 & 1 & & & & \\
$\mathrm{NO}_{2}^{-}$ & 0.276 & 0.411 & 0.408 & 0.413 & 0.462 & 0.936 & 1 & & & \\
$\mathrm{NO}_{3}^{-}$ & 0.065 & 0.356 & 0.356 & 0.358 & 0.105 & 0.186 & 0.298 & 1 & & \\
$\mathrm{SO}_{4}^{2-}$ & 0.387 & 0.442 & 0.444 & 0.443 & 0.541 & 0.735 & 0.605 & 0.218 & 1 & \\
$\mathrm{PO}_{4}^{3-}$ & 0.304 & -0.226 & -0.226 & -0.226 & -0.102 & -0.032 & -0.013 & -0.169 & -0.095 & 1 \\
& $\mathrm{Ca}^{2+}$ & $\mathrm{Cl}$ & $\mathrm{Na}^{+}$ & $\mathrm{K}^{+}$ & $\mathrm{Mg}^{2+}$ & $\mathrm{NH}_{4}^{+}$ & $\mathrm{NO}_{2}^{-}$ & $\mathrm{NO}_{3}^{-}$ & $\mathrm{SO}_{4}^{2-}$ & $\mathrm{PO}_{4}^{3-}$ \\
\hline
\end{tabular}

Table 3. Correlation coefficient of element in Dry-wet period

\begin{tabular}{lccccccccccc}
\hline $\mathrm{Ca}^{2+}$ & 1 & & & & & & & & & \\
$\mathrm{Cl}^{-}$ & 0.428 & 1 & & & & & & & & \\
$\mathrm{Na}^{+}$ & 0.428 & 1 & 1 & & & & & & & \\
$\mathrm{~K}^{+}$ & 0.419 & 0.999 & 0.999 & 1 & & & & & & \\
$\mathrm{Mg}^{2+}$ & 0.559 & 0.362 & 0.362 & 0.343 & 1 & & & & & \\
$\mathrm{NH}_{4}^{+}$ & 0.481 & 0.359 & 0.359 & 0.365 & 0.17 & 1 & & & & \\
$\mathrm{NO}_{2}^{-}$ & -0.229 & 0.095 & 0.095 & 0.101 & -0.171 & 0.292 & 1 & & & \\
$\mathrm{NO}_{3}{ }^{-}$ & -0.664 & -0.321 & -0.32 & -0.322 & -0.398 & -0.481 & 0.349 & 1 & & \\
$\mathrm{SO}_{4}^{2-}$ & 0.476 & 0.45 & 0.45 & 0.429 & 0.534 & -0.145 & -0.11 & -0.261 & 1 & \\
$\mathrm{PO}_{4}^{3-}$ & 0.036 & -0.007 & -0.007 & 0.003 & -0.128 & 0.051 & 0.127 & -0.392 & 0.052 & 1 \\
& $\mathrm{Ca}^{2+}$ & $\mathrm{Cl}$ & $\mathrm{Na}^{+}$ & $\mathrm{K}^{+}$ & $\mathrm{Mg}^{2+}$ & $\mathrm{NH}_{4}^{+}$ & $\mathrm{NO}_{2}^{-}$ & $\mathrm{NO}_{3}^{-}$ & $\mathrm{SO}_{4}^{2-}$ & $\mathrm{PO}_{4}^{3-}$ \\
\hline
\end{tabular}


Table 4. Correlation coefficient of element in Wet period

\begin{tabular}{lccccccccccc}
\hline $\mathrm{Ca}^{2+}$ & 1 & & & & & & & & & \\
$\mathrm{Cl}^{-}$ & 0.169 & 1 & & & & & & & & \\
$\mathrm{Na}^{+}$ & 0.168 & 0.999 & 1 & & & & & & & \\
$\mathrm{~K}^{+}$ & 0.175 & 0.998 & 0.998 & 1 & & & & & & \\
$\mathrm{Mg}^{2+}$ & 0.539 & 0.484 & 0.476 & 0.486 & 1 & & & & & \\
$\mathrm{NH}_{4}^{+}$ & 0.06 & 0.123 & 0.121 & 0.137 & 0.077 & 1 & & & & \\
$\mathrm{NO}_{2}{ }^{-}$ & -0.083 & 0.432 & 0.427 & 0.437 & 0.462 & -0.039 & 1 & & & \\
$\mathrm{NO}_{3}{ }^{-}$ & -0.059 & 0.384 & 0.385 & 0.396 & 0.021 & -0.174 & 0.144 & 1 & & \\
$\mathrm{SO}_{4}{ }^{2-}$ & 0.304 & 0.831 & 0.822 & 0.829 & 0.637 & -0.09 & 0.554 & 0.178 & 1 & \\
$\mathrm{PO}_{4}{ }^{3-}$ & 0.65 & -0.071 & -0.074 & -0.057 & -0.019 & 0.319 & -0.133 & -0.218 & 0.024 & 1 \\
& $\mathrm{Ca}^{2+}$ & $\mathrm{Cl}$ & $\mathrm{Na}^{+}$ & $\mathrm{K}^{+}$ & $\mathrm{Mg}^{2+}$ & $\mathrm{NH}_{4}^{+}$ & $\mathrm{NO}_{2}^{-}$ & $\mathrm{NO}_{3}^{-}$ & $\mathrm{SO}_{4}{ }^{2-}$ & $\mathrm{PO}_{4}{ }^{3-}$ \\
\hline
\end{tabular}

Table 5. Correlation coefficient of element in Wet-dry period

\begin{tabular}{lccccccccccc}
\hline $\mathrm{Ca}^{2+}$ & 1 & & & & & & & & & \\
$\mathrm{Cl}^{-}$ & 0.275 & 1 & & & & & & & & \\
$\mathrm{Na}^{+}$ & 0.275 & 1 & 1 & & & & & & & \\
$\mathrm{~K}^{+}$ & 0.259 & 0.998 & 0.998 & 1 & & & & & & \\
$\mathrm{Mg}^{2+}$ & 0.338 & 0.119 & 0.119 & 0.124 & 1 & & & & & \\
$\mathrm{NH}_{4}^{+}$ & -0.103 & 0.115 & 0.115 & 0.116 & 0.05 & 1 & & & & \\
$\mathrm{NO}_{2}^{-}$ & -0.204 & 0.317 & 0.317 & 0.326 & 0.399 & 0.401 & 1 & & & \\
$\mathrm{NO}_{3}^{-}$ & 0.085 & 0.632 & 0.632 & 0.646 & 0.161 & 0.28 & 0.411 & 1 & & \\
$\mathrm{SO}_{4}{ }^{2-}$ & 0.576 & 0.648 & 0.648 & 0.628 & 0.299 & -0.113 & -0.12 & 0.14 & 1 & \\
$\mathrm{PO}_{4}^{3-}$ & 0.112 & 0.246 & 0.246 & 0.255 & 0.262 & 0.677 & 0.686 & 0.232 & -0.055 & 1 \\
& $\mathrm{Ca}^{2+}$ & $\mathrm{Cl}$ & $\mathrm{Na}^{+}$ & $\mathrm{K}^{+}$ & $\mathrm{Mg}^{2+}$ & $\mathrm{NH}_{4}^{+}$ & $\mathrm{NO}_{2}^{-}$ & $\mathrm{NO}_{3}^{-}$ & $\mathrm{SO}_{4}^{2-}$ & $\mathrm{PO}_{4}^{3-}$ \\
\hline
\end{tabular}

\subsubsection{Cluster Analysis}

Cluster analysis is a classification method that is used to arrange a set of cases into clusters (Corter, 1996). The aim is to establish a set of clusters such that cases within a cluster are more similar to each other than they are to cases in other clusters. The actual measure of dissimilarity will depend upon the method used. It may be a similarity measure or a distance measure. Distances between points can be calculated by using an extension of Pythagorus (these are euclidean distances). These measures of 'dissimilarity' can be extended to more than two variables (dimensions) without difficulty (Corter, 1996). Euclidean distance is probably the most commonly chosen type of distance. It simply the geometric distance in the multidimensional space. It is computed as: Distance $(\mathrm{x}, \mathrm{y})=\left\{\sum_{\mathrm{i}}\left(\mathrm{x}_{\mathrm{i}}\right.\right.$ $\left.\left.-\mathrm{y}_{\mathrm{i}}\right)^{2}\right\}^{1 / 2}$ and this is why agglomerative hierarchical clustering is used in this work. Every case is initially considered a cluster, and then the two cases with the lowest distance (or highest similarity) are combined into a cluster. The case with the lowest distance to either of the first two is considered next. If the third case is closer to a fourth case than it is to either of the first two, the third and fourth cases become the second two-case cluster; if not, the third case is added to the first cluster. The process is repeated, adding cases to existing clusters, creating new clusters, or combining clusters to get to the desired final number of clusters. The result is displayed in the form of a two-dimensional diagram known as a dendrogram or tree diagram (Figures 3-5). Distance measures how far apart two observations are. Cases which are alike share a low distance. Similarity measures how alike two cases are. Cases which are alike share a high similarity (Kachigan, 1982; Corter, 1996). From the dendrogram/tree diagram for intrusive (Figure 3) we can see that THB, total coliform, $\mathrm{Mn}, \mathrm{NO}_{3}^{-}, \mathrm{K}^{+}$, faecal, $\mathrm{NH}_{4}{ }^{+}, \mathrm{PO}_{4}{ }^{2-}, \mathrm{NO}_{2}{ }^{-}, \mathrm{SO}_{4}{ }^{2-}, \mathrm{Zn}$, $\mathrm{Fe}, \mathrm{BOD}, \mathrm{DO}, \mathrm{pH}$ cluster at the minimum distance (maximum similarity) level. When the allowable distance is increased to 100 , temperature and $\mathrm{Na}^{+}, \mathrm{Cl}^{-}$which are in the same cluster is added followed by $\mathrm{Ca}_{2}{ }^{+}, \mathrm{Mg}_{2}{ }^{+}$, and Color which are at the distance of 150,200,300 respectively then join with the cluster of $\mathrm{HCO}_{3}^{-}$, Alkilinity and Conductivity then Total hardness is added last with the distances of 1225. In Asu-River group the dendrogram is 
similar to that of intrusive and all the elements behave the same, exception of conductivity which distances increases from 275 in intrusive to 1900 in Asu-River group indicating less (salts) $\mathrm{Na}^{+}, \mathrm{SO}_{4}{ }^{2-}$, and $\mathrm{PO}_{4}{ }^{3-}$ in the reaction. Dendrogram for Eze-Aku Formation reveal the clustering of the following element at minimum distance of 50: $\mathrm{Mn}, \mathrm{K}^{+}$, THB, faecal coliform, $\mathrm{NH}_{4}{ }^{+}, \mathrm{PO}_{4}{ }^{3-}, \mathrm{SO}_{4}{ }^{2-}, \mathrm{NO}_{2}^{-}, \mathrm{Fe}, \mathrm{BOD}, \mathrm{NO}_{3}^{-}, \mathrm{DO}, \mathrm{pH}$ and at the distance of 100 , Total coliform, temperature was added to the cluster. $\mathrm{Na}^{+}, \mathrm{Cl}^{-}$are in the next cluster at the distance of 500 followed by cluster of $\mathrm{Mg}^{+}$and $\mathrm{Ca}^{2+}$ at 525. Color joins the cluster alone at 600 followed by cluster of $\mathrm{HCO}_{3}{ }^{-}$and Alkalinity at the distance of 1600. Conductivity in Eze-Aku formation behaves' the same as in Asu-River group at the distance of 1700 and the lest element in the clustering is total hardness at the distance of 2800 .

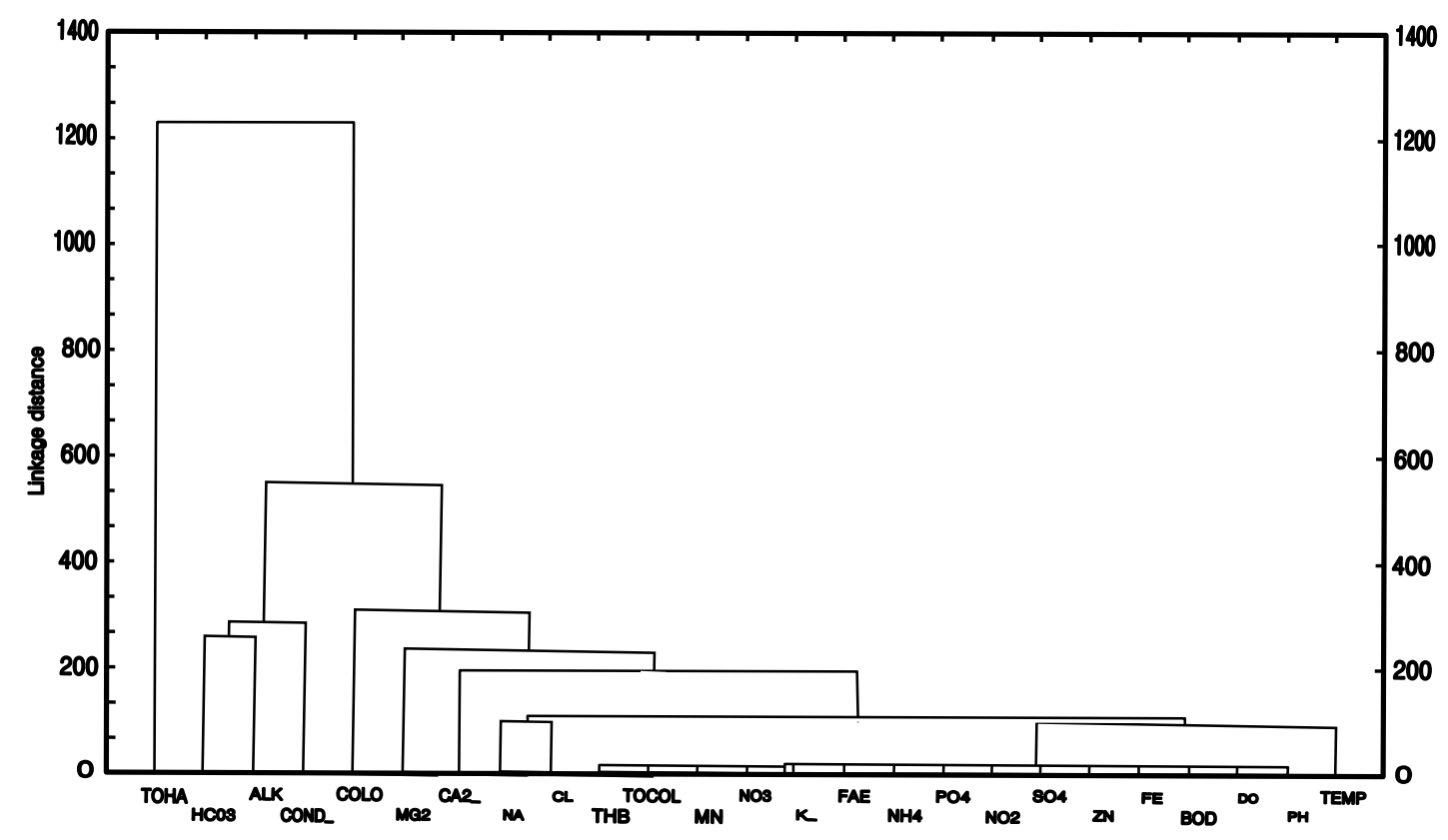

Figure 3. Tree Diagram for water Analysis for Intrusive

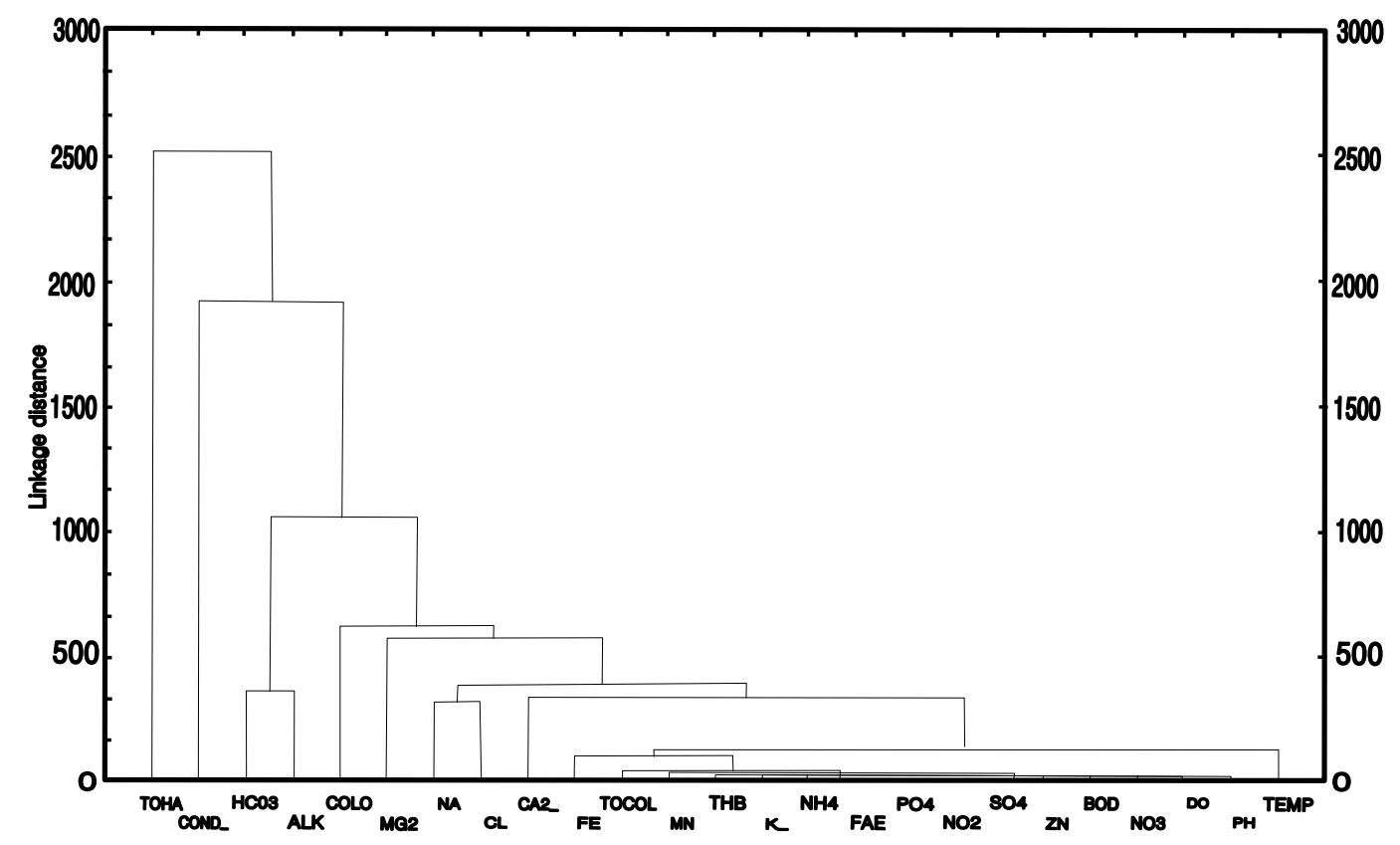

Figure 4. Tree Diagram for water Analysis for Asu-River Group 


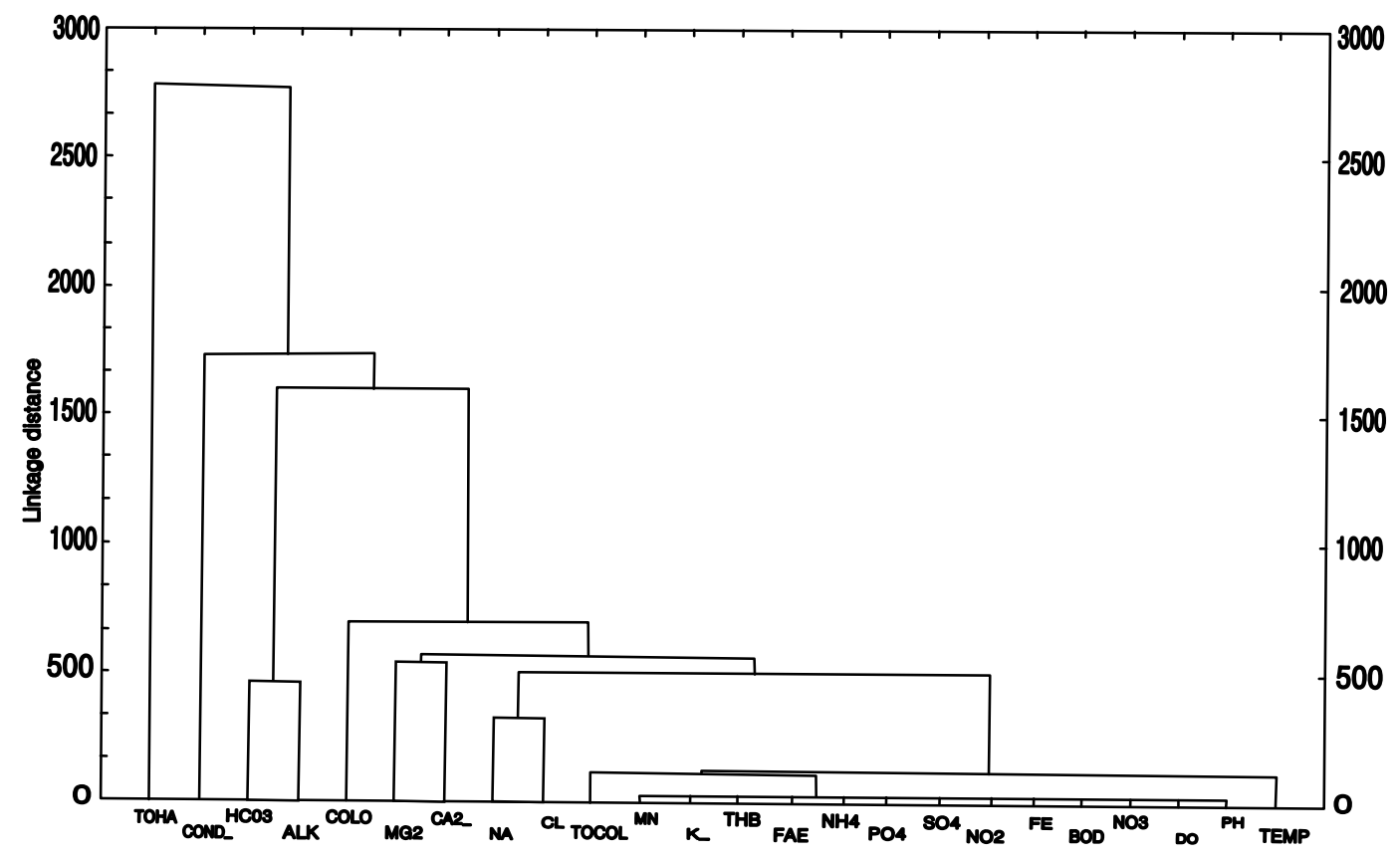

Figure 5. Tree Diagram for water Analysis for Eze-Aku Formation

\subsubsection{Factor Analysis}

In the present study, the factor analysis was used as an alternative tool for corroboration of the concept obtained from molar concentrations. Factor analyses serve for basic, independent dimensions of variables. With the help of linear combinations, an originally large number of variables are reduced to a few factors. These factors can be interpreted in terms of new variables. Factor analysis aims to explain observed relation between numerous variables in term of simpler relations. It is also a way of classifying manifestation of variables (Cattel, 1965). Factor analysis is used here as a numerical method of discovering variables that are more important than others for representing parameter variation and identifying hydrogeochemical processes. The factor model used is expressed as:

$$
X_{j}=\sum_{r=1}^{p} a_{j r} f_{r} \varepsilon_{j}
$$

where $f_{r}$ are the $r^{\text {th }}$ common factors, $p$ is the specified number of factors, ' $j$ ' is the random variation unique to the original variable $\mathrm{X}_{\mathrm{j}}, \mathrm{a}_{\mathrm{jr}}$ is the loading of the $\mathrm{j}^{\text {th }}$ variant on the $\mathrm{r}^{\text {th }}$ factor. It corresponds to the loading or weights on principal components. The principal component approach starts by extracting Eigenvalues and Eigenvectors of the correlation matrix and then discarding the less important of these (Davis, 1986). Eigenvectors are then transformed to the factors of the data set. The number of variables retained in the factors or communalities is obtained by squaring the elements in the factor matrix and summing the total within each variable. The magnitude of communalities is dependent upon the number of factors retained (Hatcher, 1994). Eigenvalue is the amount of variance explained by one more factor. In rotation, factor loadings like biquartimax, quartimax, equamax and varimax rotation were used and all gave similar results (Tables 6-8). Varimax being the default rotation was selected since all the different rotation gave the same result and varimax goal is to maximize the variance of the variable. Factor analysis in this study was used to reduced the variables and identify the most important variables that control the vulnerability in groundwater (Tables 6-8).

In intrusive, two significant factors explain $43 \%$ of the variance of the original set of the data. Factor 1 explain $24.89 \%$ and is associated with $\mathrm{Cl}^{-}, \mathrm{Na}^{+}, \mathrm{K}^{+}$, factor 2 explain $18.11 \%$ and is associated with conductivity, total hardness, $\mathrm{Ca}^{2+}$, alkalinity, $\mathrm{Mg}^{2+}, \mathrm{HCO}_{3}^{-}$. Factor 1 is due to water rock interaction while factor 2 is due to reaction of silicates with carbonic acid. In Asu-River group, two significant factors explain 39.69\% of the variance of the original data set. Factor 1 explains $28.68 \%$ which is associated with $\mathrm{Cl}^{-}, \mathrm{Na}^{+}, \mathrm{K}^{+}$, alkalinity, $\mathrm{SO}_{4}{ }^{2-}, \mathrm{HCO}_{3}{ }^{-}$while factor 2 explains $11.01 \%$ and is associated with biological parameters, faecal and total coliform. 
Factor 1 is due to water rock interaction and sulphate reduction by bacteria which results in high bicarbonate. Factor 2 is due to reaction of bacteria on organic matters and infiltration of runoff into the vodose zone. In Eze-Aku Formation, two factors explain $48.41 \%$ of the variance of the data set. Factor 1 explains $28.04 \%$ and is associated with $\mathrm{Fe}$, THB, faecal and total coliform and color. Factor 2 explains $20.37 \%$ and is associated with $\mathrm{Cl}^{-}, \mathrm{Na}^{+}, \mathrm{K}^{+}$, alkalinity and $\mathrm{HCO}_{3}{ }^{-}$. Factor 1 is due to reaction of bacteria on organic matters and infiltration of runoff into water table through the vodose zone. Factor 2 is due to water rock interaction/ dissolution of carbonates.

Table 6. Factor Analysis of parameters in Intrusive rock in the study area factor loadings (Varimaxraw)

\begin{tabular}{|c|c|c|}
\hline Variable & Factor 1 & Factor 2 \\
\hline Temperature $\left({ }^{\circ} \mathrm{C}\right)$ & -0.2297 & 0.6180 \\
\hline Conductivity $(\mu \mathrm{sm} / \mathrm{cm})$ & 0.2445 & 0.8194 \\
\hline $\mathrm{pH}$ & -0.1893 & 0.5092 \\
\hline $\mathrm{DO}(\mathrm{mg} / \mathrm{l})$ & 0.6329 & 0.0770 \\
\hline $\mathrm{BOD}(\mathrm{mg} / \mathrm{l})$ & 0.4419 & 0.3412 \\
\hline Total hardness & 0.3275 & 0.8284 \\
\hline $\mathrm{Ca}^{2+}(\mathrm{mg} / \mathrm{l})$ & -0.2176 & 0.7641 \\
\hline $\mathrm{Cl}-(\mathrm{mg} / \mathrm{l})$ & -0.8097 & -0.1586 \\
\hline $\mathrm{Na}^{+}(\mathrm{mg} / \mathrm{l})$ & -0.8096 & -0.1586 \\
\hline $\mathrm{K}^{+}(\mathrm{mg} / \mathrm{l})$ & -0.8121 & -0.1669 \\
\hline Alkalinity(mg/l) & -0.1088 & 0.7837 \\
\hline $\mathrm{Mg}_{2}^{+}(\mathrm{mg} / \mathrm{l})$ & 0.3226 & 0.7773 \\
\hline $\mathrm{Fe}(\mathrm{mg} / \mathrm{l})$ & 0.5990 & 0.0508 \\
\hline $\mathrm{Zn}$ & 0.1324 & -0.4047 \\
\hline $\operatorname{Mn}(m g / l)$ & 0.6540 & -0.3135 \\
\hline $\mathrm{NH}_{4}^{+}(\mathrm{mg} / \mathrm{l})$ & 0.3180 & 0.1559 \\
\hline $\mathrm{NO}_{2}^{-}(\mathrm{mg} / \mathrm{l})$ & -0.0194 & 0.1739 \\
\hline $\mathrm{NO}_{3}^{-}(\mathrm{mg} / \mathrm{l})$ & -0.1818 & 0.1809 \\
\hline $\mathrm{SO}_{4}^{2-}(\mathrm{mg} / \mathrm{l})$ & 0.6206 & 0.1726 \\
\hline $\mathrm{PO}_{4}{ }^{3-}(\mathrm{mg} / \mathrm{l})$ & -0.3755 & -0.1819 \\
\hline $\operatorname{THB}\left(10^{3} \mathrm{cfc} / \mathrm{ml}\right)$ & -0.0427 & -0.0219 \\
\hline Faecal coli/100ml & 0.6323 & -0.1083 \\
\hline Total coli $/ 100 \mathrm{ml}$ & 0.6437 & -0.1081 \\
\hline Color(Pt-Co) & 0.6338 & 0.1267 \\
\hline $\mathrm{HCO}_{3}^{-}$ & 0.0832 & 0.7877 \\
\hline Expl. Var & 5.6744 & 5.0765 \\
\hline Prp. Total & 0.2270 & 0.2031 \\
\hline Eigenval & 6.2236 & 4.5272 \\
\hline \%Toatal variance & 24.8945 & 18.1090 \\
\hline Cumul. Eigenval & 6.2236 & 10.7509 \\
\hline Cumul \% & 24.8945 & 43.0034 \\
\hline
\end{tabular}

Element that are relevant in the factor are $> \pm .7000$ 
Table 7. Factor Analysis of parameters in Asu-River Group in the study area factor loadings (Varimax raw)

\begin{tabular}{|c|c|c|}
\hline Variable & Factor 1 & Factor 2 \\
\hline Temperature $\left({ }^{\circ} \mathrm{C}\right)$ & 0.0312 & -0.14470 \\
\hline Conductivity $(\mu \mathrm{sm} / \mathrm{cm})$ & -0.1556 & -0.1576 \\
\hline $\mathrm{pH}$ & 0.1830 & 0.1387 \\
\hline $\mathrm{DO}(\mathrm{mg} / \mathrm{l})$ & -0.2695 & -0.0424 \\
\hline $\mathrm{BOD}(\mathrm{mg} / \mathrm{l})$ & 0.1007 & -0.0672 \\
\hline Total hardness & 0.6797 & 0.1236 \\
\hline $\mathrm{Ca}^{2+}(\mathrm{mg} / \mathrm{l})$ & 0.6364 & -0.0070 \\
\hline $\mathrm{Cl}-(\mathrm{mg} / \mathrm{l})$ & 0.9269 & 0.0013 \\
\hline $\mathrm{Na}^{+}(\mathrm{mg} / \mathrm{l})$ & 0.9267 & 0.0017 \\
\hline $\mathrm{K}^{+}(\mathrm{mg} / \mathrm{l})$ & 0.9268 & 0.0033 \\
\hline Alkalinity(mg/l) & 0.8995 & 0.1572 \\
\hline $\mathrm{Mg}_{2}^{+}(\mathrm{mg} / \mathrm{l})$ & 0.6715 & 0.1556 \\
\hline $\mathrm{Fe}(\mathrm{mg} / \mathrm{l})$ & -0.0230 & 0.1688 \\
\hline $\mathrm{Zn}$ & 0.0125 & -0.4943 \\
\hline $\mathrm{Mn}(\mathrm{mg} / \mathrm{l})$ & 0.6333 & 0.0565 \\
\hline $\mathrm{NH}_{4}^{+}(\mathrm{mg} / \mathrm{l})$ & -0.1500 & 0.5227 \\
\hline $\mathrm{NO}_{2}^{-}(\mathrm{mg} / \mathrm{l})$ & 0.3297 & 0.2294 \\
\hline $\mathrm{NO}_{3}^{-}(\mathrm{mg} / \mathrm{l})$ & 0.1420 & 0.0826 \\
\hline $\mathrm{SO}_{4}{ }^{2-}(\mathrm{mg} / \mathrm{l})$ & 0.7235 & 0.0811 \\
\hline $\mathrm{PO}_{4}{ }^{3-}(\mathrm{mg} / \mathrm{l})$ & -0.2165 & 0.5624 \\
\hline $\operatorname{THB}\left(10^{3} \mathrm{cfc} / \mathrm{ml}\right)$ & -0.2093 & -0.6929 \\
\hline Faecal coli/ $100 \mathrm{ml}$ & -0.1529 & -0.8530 \\
\hline Total coli $/ 100 \mathrm{ml}$ & -0.2075 & -0.8107 \\
\hline Color(Pt-Co) & -0.2381 & -0.1395 \\
\hline $\mathrm{HCO}_{3}^{-}$ & 0.8995 & 0.1571 \\
\hline Expl. Var & 6.9449 & 2.9763 \\
\hline Proportion. Total & 0.2778 & 0.1191 \\
\hline Eigenval & 7.1698 & 2.7514 \\
\hline \%Toatal variance & 28.6793 & 11.0056 \\
\hline Cumul. Eigenval & 7.1698 & 9.9212 \\
\hline Cumul \% & 28.6793 & 39.6849 \\
\hline
\end{tabular}

Element that are relevant in the factor are $> \pm .7000$ 
Table 8. Factor Analysis of parameters in Eze-Aku Formation in the study area factor loadings (Varimax raw)

\begin{tabular}{|c|c|c|}
\hline Variable & Factor 1 & Factor 2 \\
\hline Temperature $\left({ }^{\circ} \mathrm{C}\right)$ & 0.1830 & 0.0142 \\
\hline $\operatorname{Conductivity}(\mu \mathrm{sm} / \mathrm{cm})$ & 0.4848 & 0.2663 \\
\hline $\mathrm{pH}$ & -0.0171 & 0.2387 \\
\hline $\mathrm{DO}(\mathrm{mg} / \mathrm{l})$ & -0.2771 & -0.5097 \\
\hline $\mathrm{BOD}(\mathrm{mg} / \mathrm{l})$ & 0.02919 & -0.2089 \\
\hline Total hardness & 0.5306 & 0.1494 \\
\hline $\mathrm{Ca}^{2+}(\mathrm{mg} / \mathrm{l})$ & 0.5670 & -0.0120 \\
\hline $\mathrm{Cl}-(\mathrm{mg} / \mathrm{l})$ & -0.1384 & 0.9338 \\
\hline $\mathrm{Na}^{+}(\mathrm{mg} / \mathrm{l})$ & -0.1380 & 0.9341 \\
\hline $\mathrm{K}^{+}(\mathrm{mg} / \mathrm{l})$ & -0.1379 & 0.9336 \\
\hline Alkalinity(mg/l) & 0.3378 & 0.8742 \\
\hline $\mathrm{Mg}_{2}^{+}(\mathrm{mg} / \mathrm{l})$ & 0.3399 & 0.2559 \\
\hline $\mathrm{Fe}(\mathrm{mg} / \mathrm{l})$ & 0.8538 & 0.0528 \\
\hline $\mathrm{Mn}(\mathrm{mg} / \mathrm{l})$ & 0.1530 & 0.5424 \\
\hline $\mathrm{NH}_{4}^{+}(\mathrm{mg} / \mathrm{l})$ & 0.6139 & 0.3595 \\
\hline $\mathrm{NO}_{2}^{-}(\mathrm{mg} / \mathrm{l})$ & -0.0148 & 0.5207 \\
\hline $\mathrm{NO}_{3}^{-}(\mathrm{mg} / \mathrm{l})$ & -0.1875 & 0.1775 \\
\hline $\mathrm{SO}_{4}{ }^{2-}(\mathrm{mg} / \mathrm{l})$ & -0.0916 & 0.2621 \\
\hline $\mathrm{PO}_{4}{ }^{3-}(\mathrm{mg} / \mathrm{l})$ & 0.0614 & -0.2482 \\
\hline $\operatorname{THB}\left(10^{3} \mathrm{cfc} / \mathrm{ml}\right)$ & 0.9268 & -0.0528 \\
\hline Faecal coli/100ml & 0.9511 & -0.03498 \\
\hline Total coli $/ 100 \mathrm{ml}$ & 0.9484 & 0.0041 \\
\hline Color(Pt-Co) & 0.9474 & 0.0648 \\
\hline $\mathrm{HCO}_{3}^{-}$ & 0.3378 & 0.8742 \\
\hline Expl. Var & 6.0877 & 5.5316 \\
\hline Prp. Total & 0.2537 & 0.2305 \\
\hline Eigenval & 6.7307 & 4.8890 \\
\hline \%Toatal variance & 28.0432 & 20.3707 \\
\hline Cumul. Eigenval & 6.7304 & 11.6193 \\
\hline Cumul \% & 28.0432 & 48.4139 \\
\hline
\end{tabular}

Element that are relevant in the factor and are $> \pm .7000$

\section{Conclusion}

Hydrogeochemical studies and vulnerability assessment of sandstone - shale - intrusive aquifers which previously had not been documented have been assembled and analyzed in this work. The present levels of physico-chemical parameters, biological, heavy metal have been used to assess the vulnerability of sandstone - shale - intrusive aquifer in the study area. In physiochemical parameters, more than $70 \%$ of the parameters are below the W.H.O (2001) standard value for drinking and domestic purposes. More than $65 \%$ of biological parameters are below W.H.O standard while the other percentage of more than $25 \%$ are higher than W.H.O standard and was noticed to increased during wet and wet-dry period and reduces during dry period which show an increase due to infiltration. It was also noticed to increase from Asu River group to Eze-Aku Formation. More than $40 \%$ of the heavy metal was higher than the W.H.O (2001) standard values. The data obtained show that contamination or increase in parameters follow the flow direction of ground water. It was also observed that the Eze-Aku Formation was more 
vulnerable to coliform than the Asu-River Group followed by the Intrusive. The data also show that the formations were more vulnerable in the wet period in some area than dry period while in some area the wet period produces the vulnerability due to dilution from run off and this is evidence that the vulnerability of the study area is control by infiltration and runoff. And these goes further to show that the aquifer in the study area is mostly recharged by precipitation. The data also show that the aquifers in the study area are not vulnerable to nitrate, but are rather vulnerable to faecal coliform due to water from runoff that infiltrate into the aquifer from the vodoze zone during precipitation in the area.

\section{References}

Brunett, J. O., Barber, N. L., Burns, A. W., Fogelman, R. P., Gillies, D. C., Lidwin, R. A., \& Mack, T. J. (1997). A quality-assurance plan of district ground-water activities of the U.S. Geological Survey: U.S. Geological Survey Open-File Report 97-11, 21.

Cattel, R. B. (1965). Factor analysis: introduction to essentials. Biometric, 21, 190-125. http://dx.doi.org/10.2307/2528364

Corter, J. E. (1996). Tree models of similarity and association. Thousand Oaks, CA: Sage Publications, Quantitative Applications in the Social Sciences Series No. 112.

Cross River Basin Development Authority (CRBDA). (1982). Inventory of Natural site conditions, soil slopes, hydrology, land use and vegetation through the area of operation of the authority. Cross River Basin Development Authority Progress Report, 4, 1-154.

D'Angelo, E., Crutchfieldb, J., \& Vandiviere, M. (2001). Rapid, Sensitive, Microscale Determination of Phosphate in Water and Soil. American Journal of Environmental Quality, 30, 2206-2209. http://dx.doi.org/10.2134/jeq2001.2206

Davis, J. C. (1986). Statistics and data analysis in geology. New York: John Wiley.

Dorsch, M. M. (1984). Congenital mals and maternal drinking Water supply in rural South Australia---A case-control study. American Journal of Epidemiology, 119, 473-480.

Fan, A. M., Wilhite, C. C., \& Book, S. A. (1987). Evaluation of the Nitrate drinking water standard with reference to infant methemoglobinemia and potential reproductive toxicity. Regulatory Toxicology and pharmacology, 7, 135-137. http://dx.doi.org/10.1016/0273-2300(87)90024-9

Farrar, J. W. (1997). Results of the U.S. Geological Survey's Analytical Evaluation Program for Standard Reference Sample. U.S. Geological Survey Open-File Report, 97-553, 184 p

Hatcher, L. (1994). A step-by-step approach to using Statistic Analysis Software for factor analysis and structural equation modeling USA, Statistic Analysis Software institute Inc., Cary NC.

Hearne, G. A., Wireman, M., Campbell, A., Turner, S., \& Ingersoll, G. P. (1992). Vulnerability of the uppermost ground water to contamination in the Greater Denver area, Colorado. US Geological Survey Water-Resources Investigations Report, 92-4143, 243.

Iloeje. (1991). A New Geography of West Africa $\left(9^{\text {th }}\right.$ ed.). Nigeria Longman

Jacks, G. (1973). Chemistry of groundwater in a district in Southern India. Journals of Hydrology, 18, 185-200. http://dx.doi.org/10.1016/0022-1694(73)90047-4

Kachigan, S. K. (1982). Multivariate statistical analysis. NewYork: Radius press.

Kim, Y. J., \& Hamm, S. (1999). Assessment of the potential for ground Water contamination using the DRASTIC/EGIS technique, Cheongju area, South Korea. Hydrogeology Journal, 7(2), 227-235. http://dx.doi.org/10.1007/s100400050195

Manish, K., Ramanathan, A., Rao, M. S., \& Kumar, B. (2006). Identification and evaluation of hydrogeochemical processes in the groundwater environment of Delhi, India. Journals of Environmental Geology, 50, 1025-1039. http://dx.doi.org/10.1007/s00254-006-0275-4

Petters, S. W. (1989). Edited. A regional Hydrogeological study of rural Water supply options for planning and implementation of phase II rural water programmed in Cross River State (final volume). DFRRI, Cross River state unpublished Report, 97.

Petters, S. W., Okereke, C. S., \& Nwajide, C. S. (1987). Geology of the Mamfe Rift, South Eastern Nigeria In: Matheis, G., \& Schandelmerer, H. (Eds.) Current research in Africa Earth Sciences Balkema, Rotterdam, 299-302. 
Spurlock, D. (2005). Calcium and water quality. Natural Resources and Environmental Protection Cabinet Indiana University Southeast Indiana.

U.S. Geological Survey. (2004). Frequently Asked Questions: Why are High nitrate or nitrogen concentrations in water a problem, and what can be done to maintain safe levels?

Udom, G. J., Esu, E. O., \& Ekwere, S. J. (1998). Quality status of Groundwater in Calabar Municipality, Southeastern Nigeria. Global Journal of pure and Applied Sci., 4(2), 163-169.

World Health Organization. (2001). Drinking water Guidelines Geneva. 